\title{
Soil Formation by Ecological Factors: Critical Review
}

\author{
${ }^{1}$ Saeed Zeraat Kar and ${ }^{2}$ Aydin Berenjian \\ ${ }^{1}$ Faculty of Soil Science, Kharkov National Agrarian University, Ukraine \\ ${ }^{2}$ School of Chemical and Bimolecular Engineering, \\ Faculty of Engineering, The University of Sydney, Australia
}

Received 2013-03-11, Revised 2013-03-25; Accepted 2013-04-02

\begin{abstract}
Regolith is the term we give parent material that has been weathered. The regolith consists of weathered bedrock near the surface including the soil layer. In the Iranian soil layer we will find: decayed parent materials, decaying plant material, decaying animal matter (manure) along with vegetation. Results of the present study show us that methods stimulating natural fertility in Iran includes composting-adds humus layer, drip irrigation-balances illuviation and eluviation in arid regions, crop rotation/ intercropping-reflects natural diversity and limits gleization, add lime-reduces gleization, non-cultivation techniques-reduces hard pan (calcification) caused by compaction and reduce pesticide use-keeps decomposers alive in humus layer.
\end{abstract}

Keywords: Soils, Regolith, Parent Materials, Organic Matter, Gleization

\section{INTRODUCTION}

Eluviation is the downward movement of particles (decaying vegetation and animal waste) which occurs as water percolates into the soil from the surface. Clearly this is related to the amount of precipitation a region receives. Humans can also stimulate eluviation by irrigation. As water percolates downward, minerals from the plant and animal waste is added to the soil layer. The eluviation process is important to plants since this brings nutrients to the root zone. The greater amount of precipitation an area receives the greater the soil depth (McCarthy, 1982).

Illuviation is the upward movement of minerals from parent materials which occurs as plants extract water from the soil. This is also called evapotranspiration by geographers and is related to the region's temperature. As temperature increases during summer months, plants transpire more water to the atmosphere. To avoid wilting, roots of the plants draw water from moisture stored within the soil or aquifers beneath the soil layer. As this occurs, minerals from weathered parent material are also brought to the root zone and to the soil surface (Buol et al., 1980).
In soil science, humification is the term used to explain the downward movement of plant and animal waste into the soil layer through precipitation. Humus is necessary for sustaining soil fertility on a long term basis. Humus is the term for accumulated plant litter (leaves, decaying fruit, pollens), animal waste (manures) and decomposers (worms, earwigs). The downward movement of humus creates a deep soil layer as in mollisols or alfisols, but not found in clay based soils, such as Spodosols which limit water percolation. If humus remains along the surface (as in spodosols or vertisols), the depth of the soil layer will be limited; limiting soil fertility (Chesworth, 2008; McCarthy, 1982; Scholl et al., 2006).

\subsection{Processes Creating Soil Infertility}

Aside from Mollisols and Alfisols, many Iranian soils are infertile due to the climatic factors found in their region. Infertile soils are simply located in regions where eluviation and illuviation are not balanced and do not allow for humification.

\subsection{Laterization}

This process occurs in areas with abundant precipitation causing too_much_eluviation. This causes the nutrients from the soil surface to be leached from the soil layers. Oxisols are found in such locations. As

\section{Corresponding Author: Saeed Zeraat Kar, Faculty of Soil Science, Kharkov National Agrarian University, Ukraine}


we know, this creates very deep soils, yet does not allow the soil to retain these nutrients, creating very infertile soils. These soils look "rusted" reflecting the oxidation of iron minerals in the soil and may be best utilized as a building material.

\subsection{Salinization}

In areas with too much illuviation and limited precipitation (such as deserts), salts from parent materials are brought to the surface. Plants in arid climates have very high rates of potential transpiration (water demand). Dominant soils affected by salinization are aridisols. Plants which adapt to such conditions have long tap roots able to acquire water from subsurface storage. As salts are brought to the surface, the soils appear white. Most plants cannot tolerate much salt, creating a poor habitat for most vegetation. Irrigation on marginal soils, such as alfisols, can stimulate illuviation in these areas, leaving soils vulnerable to salinization. Irrigation may stimulate percolation (eluviation), yet transplanting varieties not adapted to high temperatures (broad leaves) causes greater amounts of evapotranspiration, or greater demand for water from such plants. Farmers can then stimulate salinization by choosing to plant crops, such as tobacco or cotton (adapted to areas with 40-60 inches of precipitation each year, in semi-arid regions, like the Central Valley (Buol et al., 1980; Retallack, 2008; Scholl et al., 2006; Milford et al., 2001).

\subsection{Calcification}

Calcification causes by too much illuviation. Arid conditions cause calcium deposits deep in soil layers to harden which limits the movement of nutrients (eluviation and illuviation). This creates what we call "hard pan" soils, found mostly in aridisols and alfisols. Similar to salinization, humans can stimulate calcification through flood irrigation as well as compacting the soil with heavy machinery, or overgrazing of animals (too many head of steer per acre). Calcification reduces the soil's Cation-Exchange Capacity (CEC). This term sounds a little frightening, but really is just describes the lack of illuviation and eluviation taking place due to the hard pan (Roesch et al., 2007; SSDS, 1993).

\subsection{Gleization}

This process is similar to calcification as a layer of soil limits eluviation and illuviation. In gleization, clay layers limit the porosity of the soil, causing plant litter and animal waste to be accumulated on the surface. Soil depth is limited and humus collects along the surface. We call these soils histosols or peat bogs (our source of commercial peat moss). These soils are found in cold climates (which limit percolation) and areas with poor drainage.

\subsection{Podzolization}

This is the process of soil acidification caused by the type of plant litter found in such regions. Some vegetation, such as tomatoes, pine trees, walnuts and tobacco, has acidic leaves. As this plant litter decays and percolates through the soil with precipitation, an acidic environment is created in which little vegetation can exist. These conditions naturally occur in pine forests, creating spodosols or ultisols. Humans can stimulate podzolization by planting acidic plants in fertile soils, such as those noted above. Lime can be added to the surface to reduce the acidity (Donahue et al., 1986; Nakano and Akikawa, 2012; PSSEL, 2013).

\subsection{Other Elements Creating Soil Fertility and Infertility in Iran}

We have discussed the dominate processes which determine Iranian soil fertility and soil infertility. Once we know the processes above, further discussion of soil color, soil texture and soil porosity are easy to comprehend. Soil texture and soil porosity are addressing the type of parent materials which make-up each soil region. The key here is clay (USDA, 2004; Copley, 2005). Clay limits the movement of water and therefore limits eluviation and illuviation. This can cause salinization, calcification and gleization. Soil color is an indicator of soil fertility. Iranian Red soils reflect too much water (oxidation and laterization), white soils reflect too much heat (causing calcification or salinization). Iranian Mollisols are nice, soft, dark soils which reflect a high amount of humus throughout the soil layers, leading to fertility (Gans et al., 2005).

\section{CONCLUSION}

Methods stimulating natural fertility in Iran include:

- Composting-adds humus layer

- Crop rotation/intercropping-reflects natural diversity and limits gleization

- Drip irrigation-balances illuviation and eluviation in arid regions

- Add lime-reduces gleization

- Reduce pesticide use-keeps decomposers alive in humus layer

- Non-cultivation techniques-reduces hard pan (calcification) caused by compaction 


\section{ACKNOWLEDGEMENT}

Researchers would like to thank professors Dr. V.V. Degtyarov, Dr. Tikhonenko and Dr. Gorin all from soil science department of Kharkov National Agrarian University in Ukraine for their continued support.

\section{REFERENCES}

Buol, S.W., R.J. McCracken and F.D. Hole, 1980. Soil Genesis and Classification. 2nd Edn., Iowa State University Press, Ames, Iowa, ISBN10: 081381460X, pp: 404.

Chesworth, W., 2008. Encyclopedia of Soil Science. 1st Edn., Springer, Netherlands, ISBN-10: 1402039948, pp: 902.

Copley, J., 2005. Millions of bacterial species revealed underfoot. New Sci., 309: 1387-1387.

Donahue, R.E., E.A. Wang, D.K. Stone, R. Kamen and G.G. Wong et al., 1986. Stimulation of haematopoiesis in primates by continuous infusion of recombinant human GM-CSF. Nature, 321: 872875. DOI: $10.1038 / 321872 \mathrm{a} 0$

Gans, J., M. Wolinsky and J. Dunbar, 2005. Computational improvements reveal great bacterial diversity and high metal toxicity in soil. Am. Assoc. Adv. Sci., 309: 1387-1390. DOI: 10.1126/science. 1112665

McCarthy, D.F., 1982. Essentials of Soil Mechanics and Foundations: Basic Geotechnics. 2nd Edn., Reston Publishing, Reston, Virginia, ISBN-10: 0835917819, pp: 632.
Milford, H.B., A.J.E. McGaw and K.J. Nixon, 2001. Soil Data Entry Handbook: For the NSW Soil and Land Information System (SALIS). 3rd Edn., NSW Dept. of Land and Water Conservation, Sydney, ISBN-10: 0734751966, pp: 72.

Nakano, M. and T. Akikawa, 2012. Literature review of empirical studies on SCM using the SSPP paradigm. Kyoto Sangyo University.

PSSEL, 2013. Soils - Part 2: Physical Properties of Soil and Soil Water. Plant and Soil Sciences eLibrary, University of California-Davis.

Retallack, G.J., 2008. Soils of the Past: An Introduction to Paleopedology. 2nd Edn., John Wiley and Sons, Chichester, ISBN-10: 0470698160, pp: 416.

Roesch, L.F., R.R. Fulthorpe, A. Riva, G. Casella and A.K. Hadwin et al., 2007. Pyrosequencing enumerates and contrasts soil microbial diversity. ISME J., 1: 283-290. PMID: 18043639

Scholl, V.L., M.M. Smits and E. Hoffland, 2006. Ectomycorrhizal weathering of the soil minerals muscovite and hornblende. New Phytol., 171: 805813. PMID: 16918551

SSDS, 1993. Soil Structure. Department of Agriculture, Soil Conservation Service, U.S.

USDA, 2004. Climate and Man: Part One. 1st Edn., University Press of the Pacific, Honolulu, Hawaii, ISBN-10: 1410215385, pp: 540. 